\title{
Use of Spilopelia senegalensis as a Biomonitor of Heavy Metal Contamination from Mining Activities in Riyadh (Saudi Arabia)
}

\author{
Ahmed M. Almalki ${ }^{1}$, Jamaan Ajarem ${ }^{1, *}$, Ahmed A. Allam ${ }^{2}$, Hamed A. El-Serehy ${ }^{1,3}$, \\ Saleh N. Maodaa ${ }^{1}$ and Ayman M. Mahmoud ${ }^{2, *}$ \\ 1 Zoology Department, College of Science, King Saud University, Riyadh 11451, Saudi Arabia; \\ Ah797979@hotmail.com (A.M.A.); helserehy@ksu.edu.sa (H.A.E.-S.); maodaa_28@yahoo.com (S.N.M.) \\ 2 Zoology Department, Faculty of Science, Beni-Suef University, Beni-Suef 62514, Egypt; \\ allam1081981@yahoo.com \\ 3 Oceanography Department, College of Science, Port Said University, Port Said 42522, Egypt \\ * Correspondence: jajarem@ksu.edu.sa (J.A.); ayman.mahmoud@science.bsu.edu.eg (A.M.M.)
}

Received: 4 November 2019; Accepted: 26 November 2019; Published: 29 November 2019

Simple Summary: Bioindicators and biomonitors are living organisms utilized to appraise the health of the environment or natural ecosystem. Mining, which refers to extraction of valuable materials from the earth, represents a source of heavy metals that can impact the environment, biodiversity, and human health. We investigated the value of the laughing dove (Spilopelia senegalensis) as a biomonitor of environmental contamination with heavy metals from mining practices. Our results revealed the accumulation of heavy metals in the liver, kidneys, and lungs of the laughing dove collected from the mining site. The doves exhibited tissue dysfunction and injury, and decreased antioxidants. These results show the value of the laughing dove as a biomonitor of environmental pollution with heavy metals.

\begin{abstract}
Environmental pollution with heavy metals (HMs) is of serious ecological and public health concern worldwide. Mining is one of the main sources of HMs and can impact the environment, species diversity, and human health. This study assessed the value of Spilopelia senegalensis as a biomonitor of environmental contamination with metal(loid)s caused by mining activities. S. senegalensis was collected from a gold mining site and a reference site, and metal(loid)s and biochemical parameters were determined. Lead, cadmium, mercury, vanadium, arsenic, copper, zinc, and iron were significantly increased in the liver, kidney, and lung of S. senegalensis from the mining site. Serum transaminases, alkaline phosphatase, creatinine, and urea were significantly elevated in S. senegalensis from the mining site. Lipid peroxidation and nitric oxide were increased, whereas glutathione and antioxidant enzymes were diminished in the liver and kidney of S. senegalensis from the mining site. In addition, multiple histological alterations were observed in the liver, kidney, and lung of $S$. senegalensis. In conclusion, mining activities provoke the accumulation of metal(loid)s, oxidative stress, and tissue injury in S. senegalensis. Therefore, S. senegalensis is a valuable biomonitor of environmental pollution caused by mining activities and could be utilized in epidemiological avian studies of human health.
\end{abstract}

Keywords: heavy metals; pollution; biomonitoring; mining; oxidative stress

\section{Introduction}

Bioindicators are living organisms utilized to appraise the health of the environment or natural ecosystem [1]. Different classes of indicator organisms may offer different responses to pollution; therefore, could they be used for biological monitoring [2]. Birds are widely distributed and occupy 
multiple habitat types and ecological niches. The presence of birds near the top of the food chain makes them sensitive to changes induced by environmental contaminants [3]. Given their well-treated classification and ease of detection in the environment [4], birds represent valuable biological indicators. In accordance, birds have been used as biomonitors to assess contamination of the environment with persistent organic pollutants, ecosystem health, biological effects of climate change, and different ecological processes [5-8]. The destructive effect of regular pollutants, such as inorganic fertilizers and pesticides, on bird populations has been explored in multiple studies [5-8]. Pollutants can also affect the breeding performance, as well as the survival, of birds [9]. In addition, exposure of birds to heavy metals (HMs) in the ecosystem is an issue of paramount importance. HMs produced through natural and anthropogenic ways can enter birds through direct inhalation, dermal contact, ingestion, and other routes [10]. In this context, pigeons have been suggested as valuable biomonitors and have been utilized in the assessment of atmospheric metal contamination in China [11].

Mining is the extraction of valuable materials and minerals from the earth. Mining practices create a negative environmental impact; therefore, most of the world's nations have passed regulations to decrease the impact of pollution from mines [12-14]. Erosion, loss of biodiversity, dust, and contamination of water bodies and soil with HMs and other chemicals are among the environmental issues related to mining activities $[15,16]$. If not properly controlled, mining-related contamination with HMs can impact the health of the local population, as well as nearby communities [17]. The hazardous effects of HMs on the ecosystem, biodiversity, and health are related to their resistance to degradation and tendency for bioaccumulation and biomagnification in the food chain until reaching humans $[18,19]$. While some HMs have no specific metabolic role, others are essential for vital processes within the living cells, but are toxic at higher concentrations [20]. The toxic effects of HMs at concentrations beyond the physiological limits have been demonstrated both in vivo and in vitro [21,22]. Neurological disorders, osteoporosis, cancer, and other disorders are associated with the chronic exposure to HMs [23]. In rodents, exposure to HMs at mining and quarrying sites was associated with their accumulation in different tissues, resulting in liver, kidney, and lung injury [24,25].

Recently, we demonstrated the accumulation of HMs produced through gold mining activities in the soil and Arabian boxthorn and their negative impact on Gerbillus nanus in Saudi Arabia [24]. Given the importance of birds as biomonitors of environmental contamination, this study investigated the impact of gold mining activities in Riyadh (Saudi Arabia) on the laughing dove (Spilopelia senegalensis), with an emphasis on HM accumulation and tissue injury.

\section{Materials and Methods}

\subsection{Collection and Processing of Samples}

Ten S. senegalensis were collected from the site of a gold mine located southwest of Al-Quway'iyah city, which is a large governorate located $165 \mathrm{~km}$ west of Riyadh Province (Saudi Arabia). The pigeons were collected within $0.5 \mathrm{~km}$ of the gold mine $\left(45^{\circ} 05^{\prime} \mathrm{E}\right.$ and $\left.23^{\circ} 47^{\prime} \mathrm{N}\right)$ using bird traps. Ten other pigeons were collected from a reference site located $20 \mathrm{~km}$ away from the mine $\left(45^{\circ} 06^{\prime} \mathrm{E}\right.$ and $\left.23^{\circ} 36^{\prime} \mathrm{N}\right)$. The reference site is a village with no industrial or mining activities (Figure 1). 


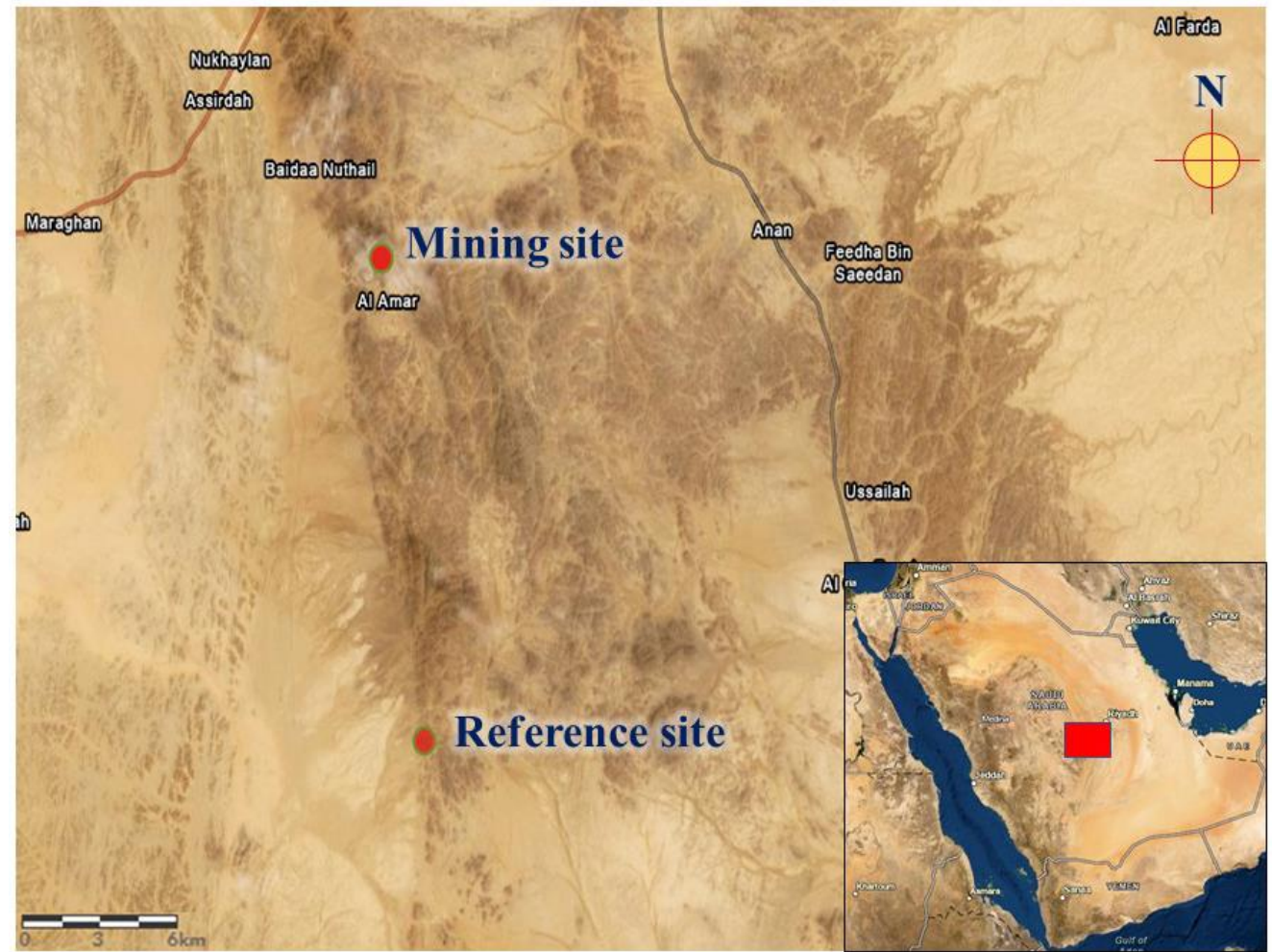

Figure 1. A map showing the location of the mining and reference sites.

The collected pigeons were transferred into the lab and immediately sacrificed, and blood was collected for serum separation. The pigeons were dissected, and the liver, kidneys, and lungs were collected, washed with ice-cold phosphate-buffered saline (PBS), and stored at $-80^{\circ} \mathrm{C}$. Samples from the liver, kidneys, and lungs were collected on $10 \%$ neutral buffered formalin. Other samples were homogenized in PBS $(10 \% w / v)$ for assaying lipid peroxidation (LPO), nitric oxide (NO), and the antioxidants reduced glutathione (GSH), superoxide dismutase (SOD), and catalase (CAT).

\subsection{Assay of HMs and Arsenic (As)}

The concentrations of lead $(\mathrm{Pb})$, cadmium $(\mathrm{Cd})$, mercury $(\mathrm{Hg})$, vanadium $(\mathrm{V})$, copper $(\mathrm{Cu})$, zinc $(\mathrm{Zn})$, iron $(\mathrm{Fe})$, and As were determined in the liver, kidney, and lung samples of $S$. senegalensis using ELAN 9000 ICP-MS (Perkin Elmer Sciex Instruments, Concord, ON, Canada). Briefly, 2 mL nitric acid was added to $200 \mathrm{mg}$ tissue sample in a clean digestion beaker. Following heating at $140{ }^{\circ} \mathrm{C}$ for $40 \mathrm{~min}$, the digest was filtered, transferred to a clean tube, and the volume was brought to $10 \mathrm{~mL}$ using Ultrapure water. A blank digest was prepared in the same way. For calibration and quality control, standard references (Aristar grade, VWR International Ltd, Leicestershire, UK) were used. The linear rank of the methodology was assured by analyzing different standards for each element, and all standards were used in duplicate to determine the precision of the analysis. Ultrapure water was used to prepare blanks and calibration standards, and three replicate determinations were performed for each sample.

\subsection{Histopathlogy}

The tissue samples collected on $10 \%$ neutral buffered formalin were fixed for $48 \mathrm{~h}$ at $4{ }^{\circ} \mathrm{C}$. The fixed samples were passed into a serial ascending grade of ethanol and xylene and embedded in paraffin wax. Then, 5- $\mu \mathrm{m}$ sections were cut and stained with hematoxylin and eosin (H\&E) [26]. In brief, the sections were deparaffinized in three changes of xylene, rehydrated through a descending series of ethanol, and stained with hematoxylin. The slides were washed in tap water and then stained with 
eosin, followed by washing in tap water and rinsing in distilled water. The sections were dehydrated in ethanol, cleared in xylene, and mounted. The stained sections were examined using Coolscope Digital light Microscope (Nikon, Japan).

\subsection{Assay of Liver and Kidney Function}

Alanine transaminase (ALT), aspartate transaminase (AST), and alkaline phosphatase (ALP) are found within the hepatocytes and can be released into the bloodstream when the liver is damaged. Therefore, increased circulating levels of these enzymes indicates hepatocyte damage. Creatinine is a breakdown product of creatine phosphate in muscle, and urea is the major nitrogenous end product of protein and amino acid catabolism. Both creatinine and urea are filtered out of blood through the glomeruli, and are therefore commonly measured as indices of glomerular function $[27,28]$. To evaluate liver and kidney function in S. senegalensis, serum ALT, AST, ALP, creatinine, and urea were determined using kits purchased from Biomerieux (France), following the provided instructions.

\subsection{Assay of LPO, NO, and Antioxidants}

Oxidative stress has been highlighted as the main culprit behind the toxic action of most pollutants [29]. Therefore, assessment of oxidative stress markers and cellular antioxidants represents a potentially important indicator of the impact of environmental stressors on birds [30]. Increased production of reactive oxygen species (ROS) can provoke tissue injury by oxidizing lipids and proteins and depleting antioxidant defenses [31]. The impact of mining on the redox balance in S. senegalensis was evaluated by the determination of LPO, NO, and antioxidants. LPO was assayed as previously described by Preuss et al. [32], and NO was determined using Griess reagent following the method of Grisham et al. [33]. The antioxidant defenses GSH, SOD, and CAT were determined according to the methods of Beutler et al. [34], Marklund and Marklund [35], and Cohen et al. [36], respectively.

To normalize the results to protein, total protein content in the homogenates was assayed using Bradford assay [37].

\subsection{Statistical Analysis}

Data are expressed as means \pm standard error of means (SEM). All statistical comparisons were performed by $t$-test using GraphPad Prism 7 (La Jolla, CA, USA). A p-value $<0.05$ was considered significant.

\section{Results}

\subsection{Concentration of Metal(loid)s in the Liver, Kidney, and Lung of S. senegalensis}

Assessment of $\mathrm{HM}$ concentrations showed significant increase in $\mathrm{Pb}, \mathrm{Cd}$, and $\mathrm{Hg}$ in the liver of $S$. senegalensis collected from the mining site when compared with the control birds $(p<0.01)$, as depicted in Figure 2A-C. Similarly, the liver of S. senegalensis from the mining site showed elevated concentrations of $\mathrm{V}(p<0.05)$, As $(p<0.01), \mathrm{Cu}(p<0.05), \mathrm{Fe}(p<0.01)$, and $\mathrm{Zn}(p<0.05)$, as represented in Figure 2D-H. 
A

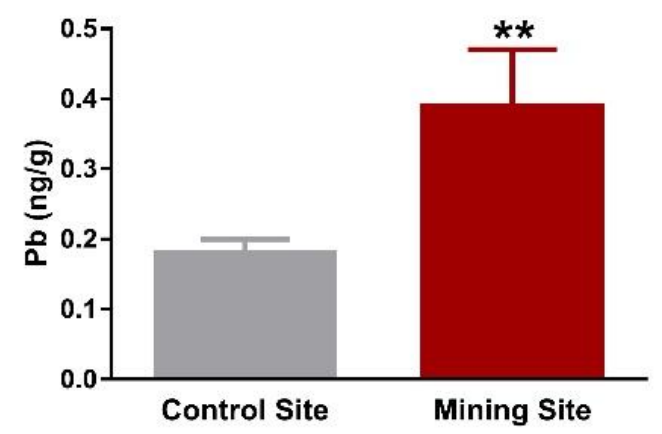

C

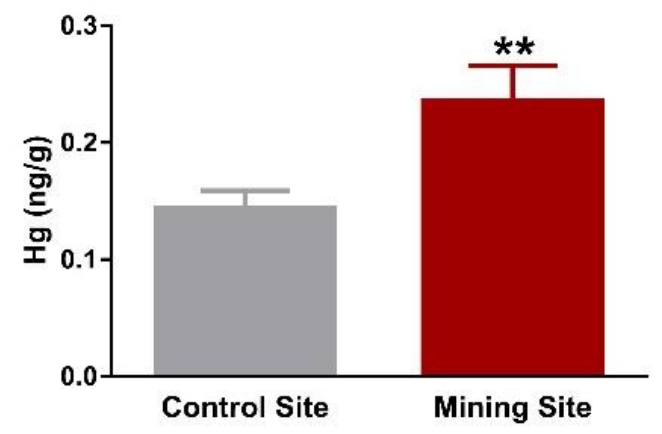

$\mathbf{E}$

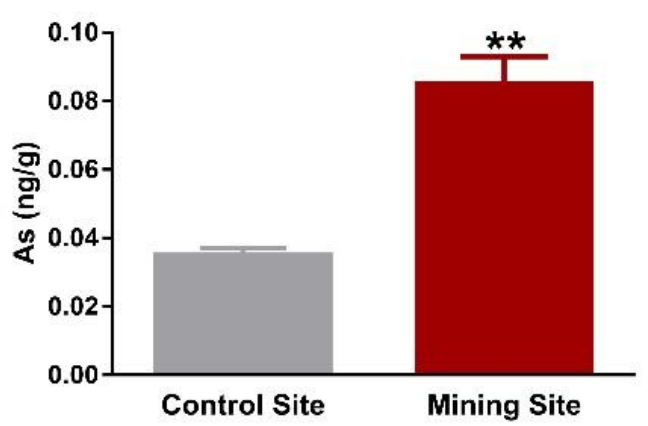

G

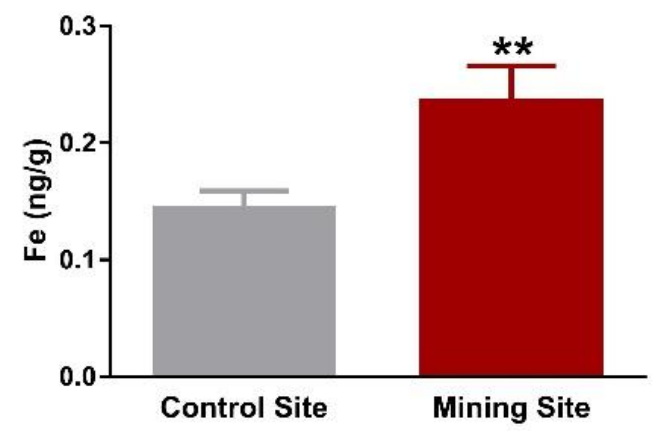

B

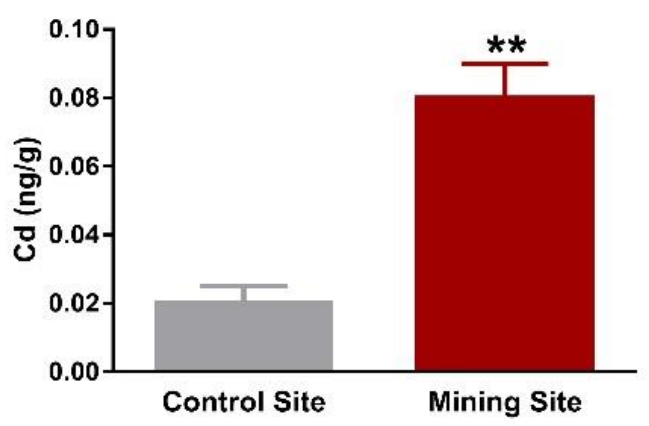

D

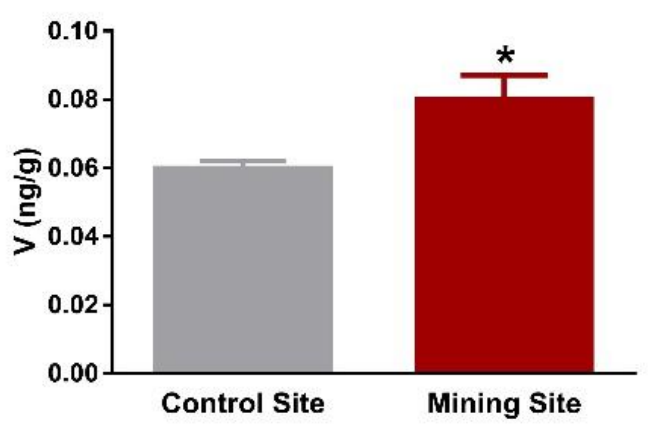

$\mathbf{F}$

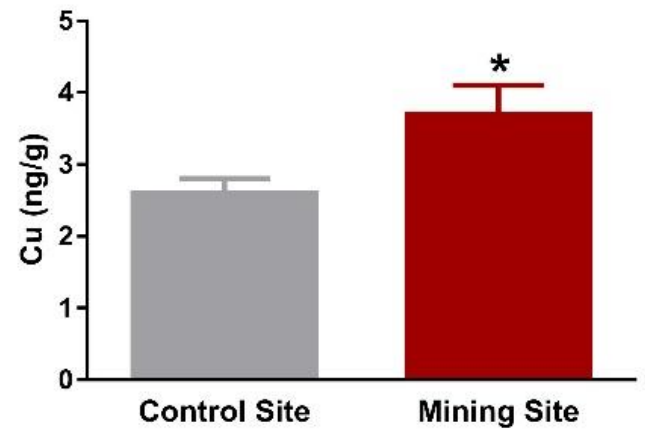

H

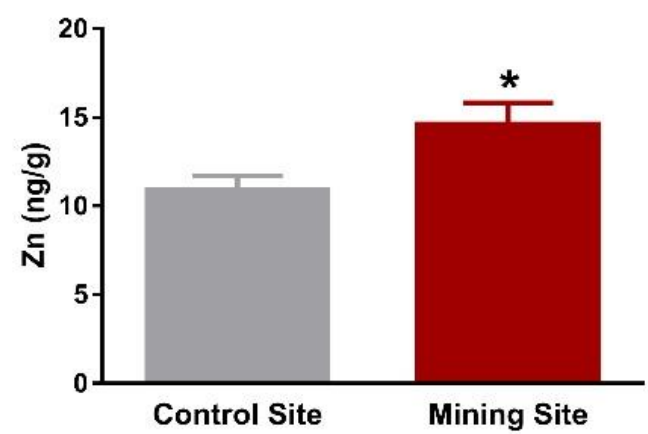

Figure 2. Concentrations of metal(loid)s in the liver of S. senegalensis. $\mathrm{Pb}(\mathbf{A}), \mathrm{Cd}(\mathbf{B}), \mathrm{Hg}(\mathbf{C}), \mathrm{V}(\mathbf{D})$, As $(\mathbf{E}), \mathrm{Cu}(\mathbf{F}), \mathrm{Fe}(\mathbf{G})$, and $\mathrm{Zn}(\mathbf{H})$ were significantly increased in the liver of $S$. senegalensis from the mining site. Data are means \pm standard error of means (SEM) $(n=10) .{ }^{*} p<0.05$ and ${ }^{* *} p<0.01$ versus the Control site. 
The kidney of $S$. senegalensis from the mining site exhibited significantly increased $\mathrm{Pb}(p<0.001)$, $\mathrm{Cd}, \mathrm{Hg}, \mathrm{V}, \mathrm{As}, \mathrm{Fe}(p<0.01), \mathrm{Cu}$, and $\mathrm{Zn}(p<0.05)$ when compared with the control group, as shown in Figure 3A-H. Similarly, $\mathrm{Pb}, \mathrm{Cd}, \mathrm{V}, \mathrm{As}, \mathrm{Cu}, \mathrm{Fe}, \mathrm{Zn}(p<0.05)$, and $\mathrm{Hg}(p<0.01)$ concentrations were significantly increased in the lung of $S$. senegalensis collected from the mining site (Figure $4 \mathrm{~A}-\mathrm{H}$ ). The differences between the concentrations of metal(loid)s in the liver, kidney, and lung of S. senegalensis collected from the mining and reference sites are summarized in Figure 5.

A

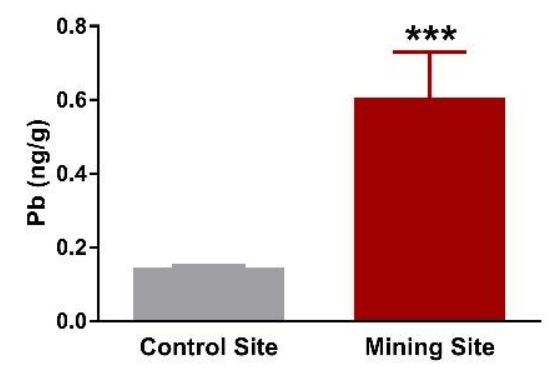

C

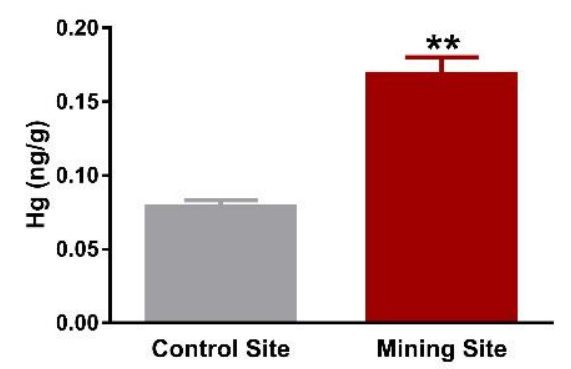

E

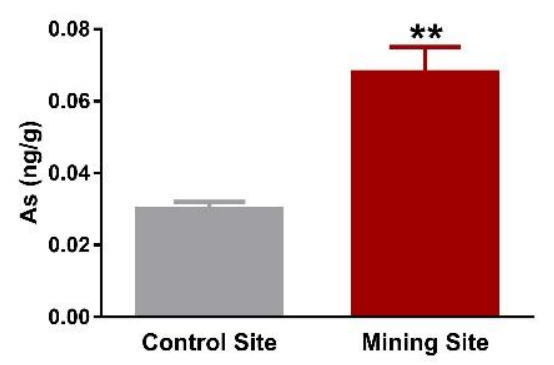

G

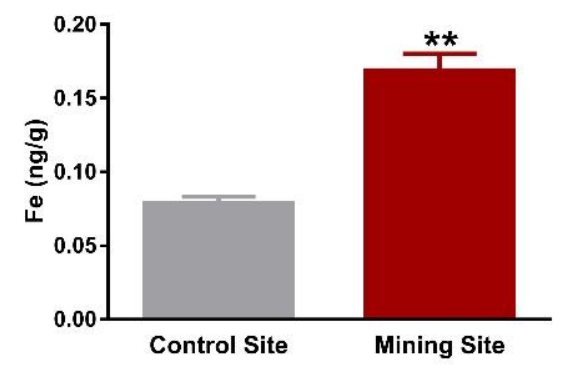

B

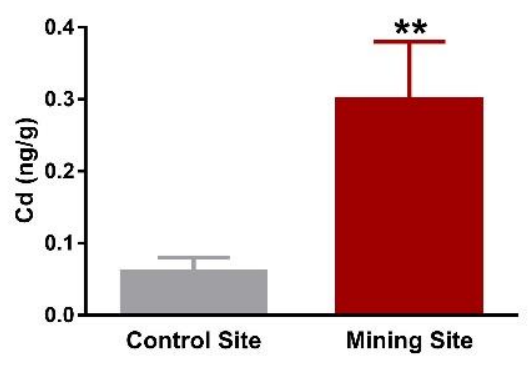

D

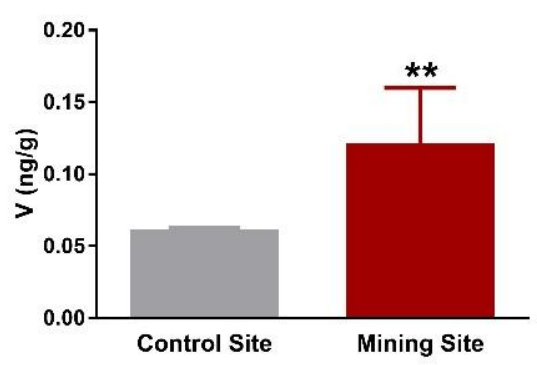

$\mathbf{F}$

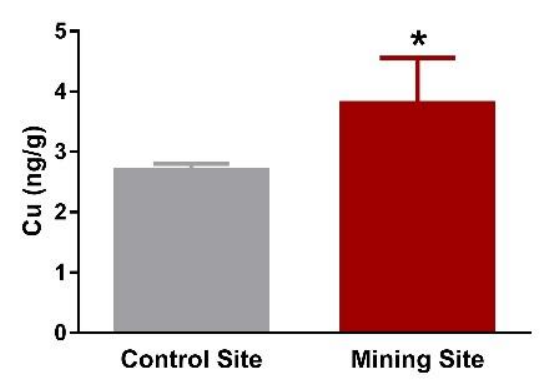

H

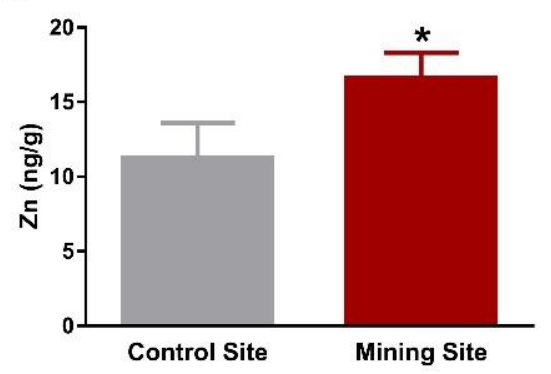

Figure 3. Concentrations of metal(loid)s in the kidney of S. senegalensis. $\mathrm{Pb}(\mathbf{A}), \mathrm{Cd}(\mathbf{B}), \mathrm{Hg}(\mathbf{C}), \mathrm{V}(\mathbf{D}), \mathrm{As}$ $(\mathbf{E}), \mathrm{Cu}(\mathbf{F}), \mathrm{Fe}(\mathbf{G})$, and $\mathrm{Zn}(\mathbf{H})$ were significantly increased in the kidney of $S$. senegalensis from the mining site. Data are means $\pm \operatorname{SEM}(n=10) .{ }^{*} p<0.05,{ }^{* *} p<0.01$, and ${ }^{* * *} p<0.001$ versus the Control site. 
A

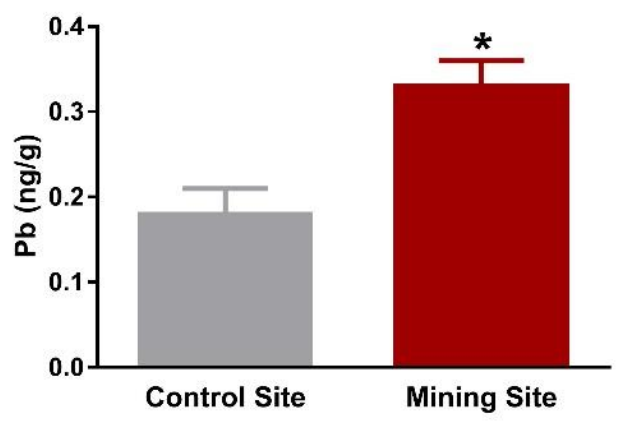

C

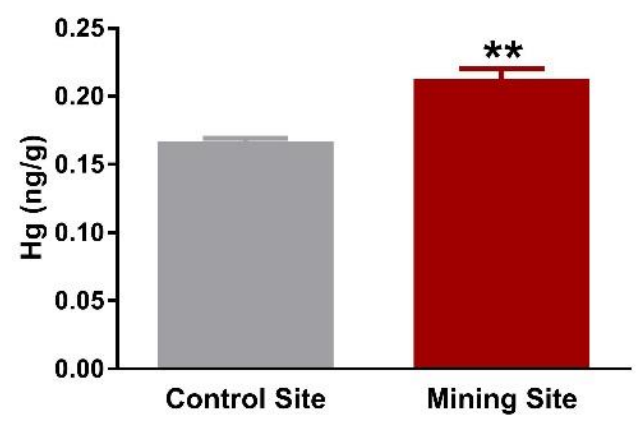

E

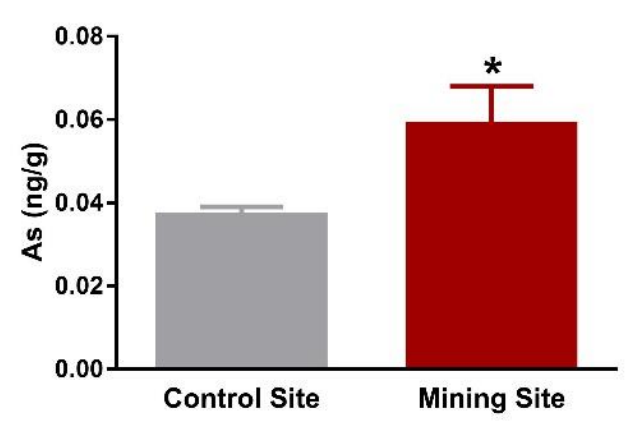

G

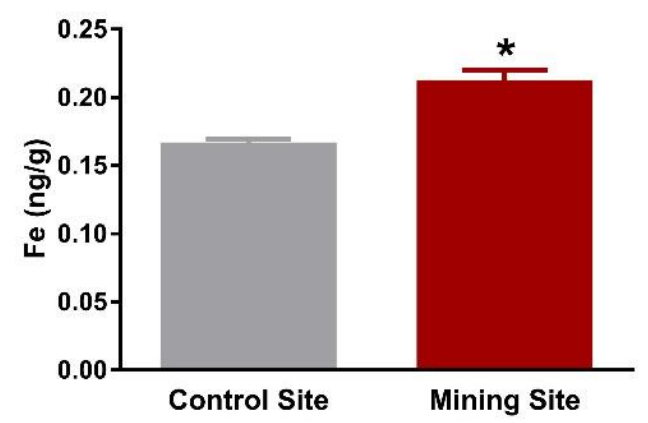

B

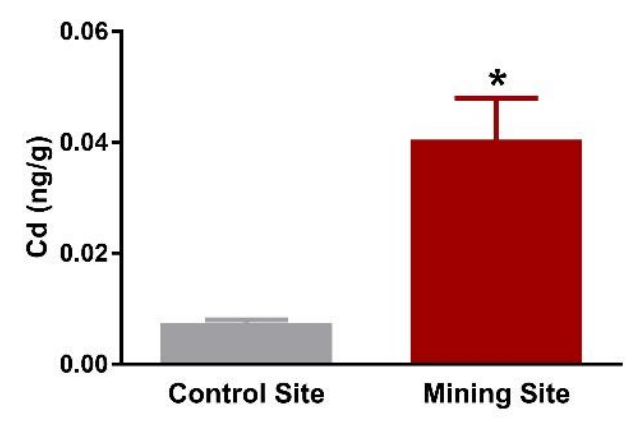

D

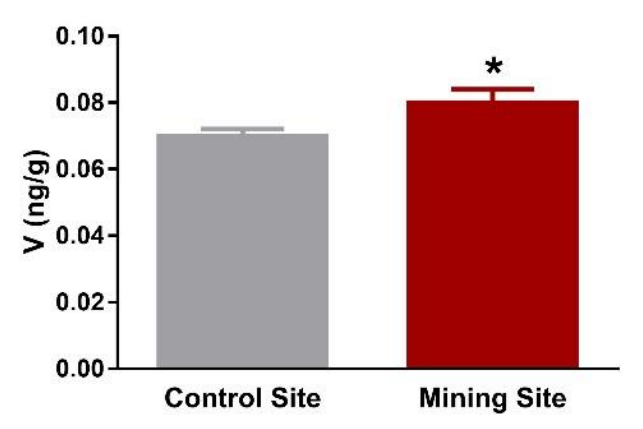

$\mathbf{F}$

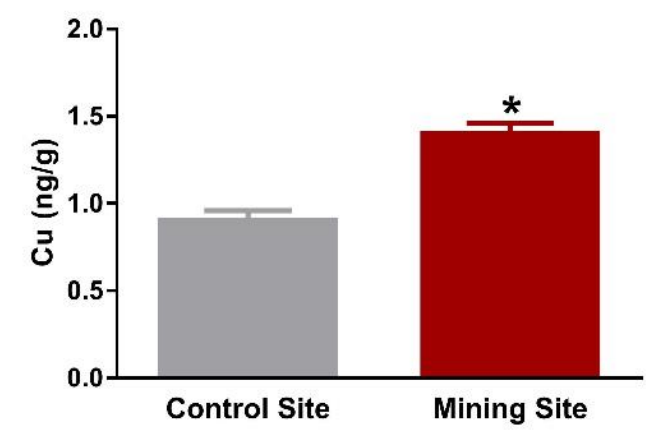

H

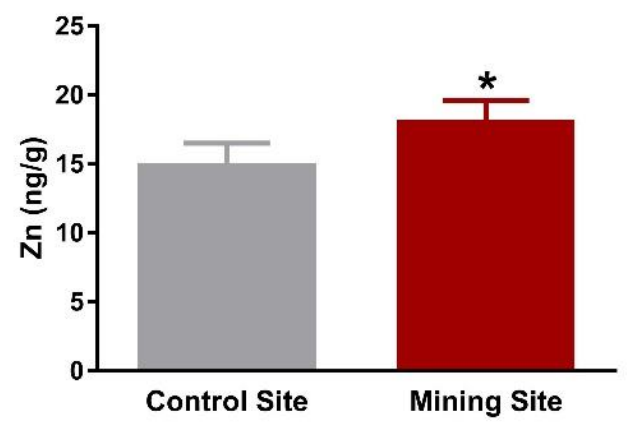

Figure 4. Concentrations of metal(loid)s in the lung of S. senegalensis. $\mathrm{Pb}(\mathbf{A}), \mathrm{Cd}(\mathbf{B}), \mathrm{Hg}(\mathbf{C}), \mathrm{V}(\mathbf{D})$, As $(\mathbf{E}), \mathrm{Cu}(\mathbf{F}), \mathrm{Fe}(\mathbf{G})$, and $\mathrm{Zn}(\mathbf{H})$ were significantly increased in the lung of $S$. senegalensis from the mining site. Data are means $\pm \operatorname{SEM}(n=10) .{ }^{*} p<0.05$ and ${ }^{* *} p<0.01$ versus the Control site. 


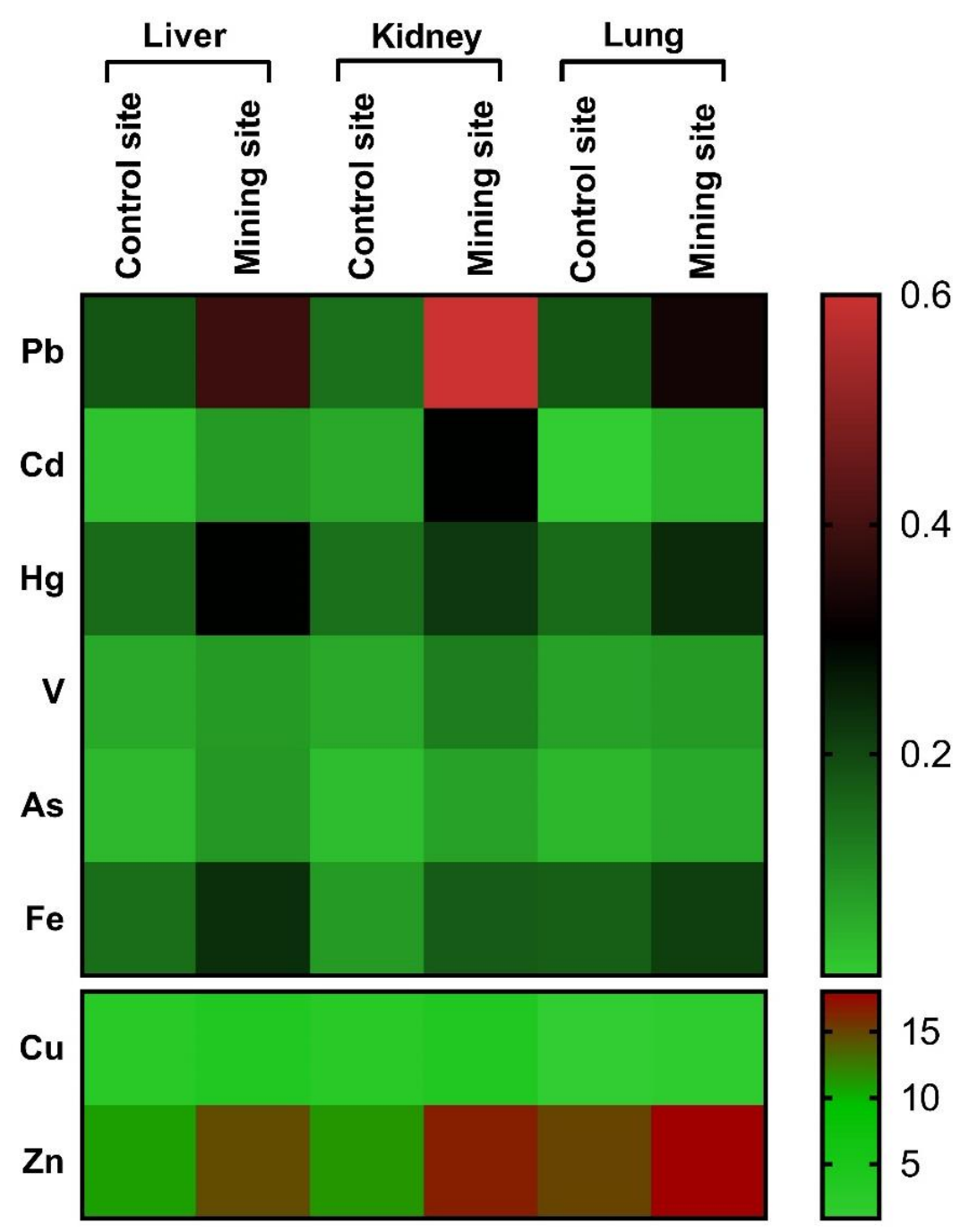

Figure 5. A heat map showing the differences between the concentrations of HMs in the liver, kidney, and lung of $S$. senegalensis collected from the mining and reference sites.

\subsection{Effect of Mining on the Liver and Kidney Function of S. senegalensis}

The liver function markers ALT, AST, and ALP were significantly elevated in the serum of $S$. senegalensis collected from the mining site $(p<0.01 ; p<0.01 ; p<0.001)$ when compared with the reference site (Figure 6A-C). Serum levels of creatinine (Figure 6D) and urea (Figure 6E) showed a significant $(p<0.05 ; p<0.01)$ increase in $S$. senegalensis collected from the mining site when compared with the reference pigeons. 
A

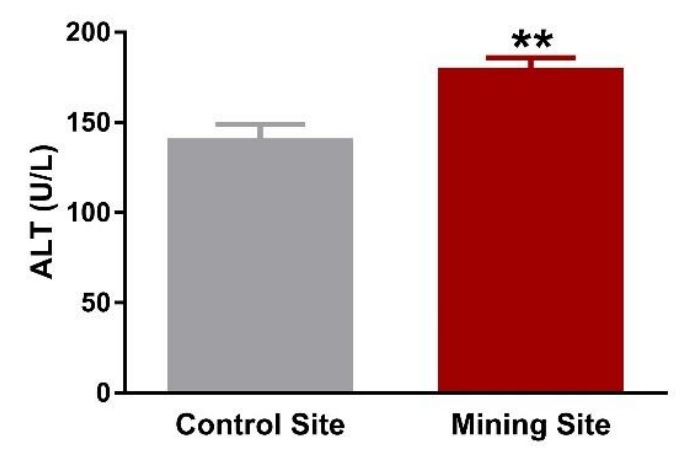

C

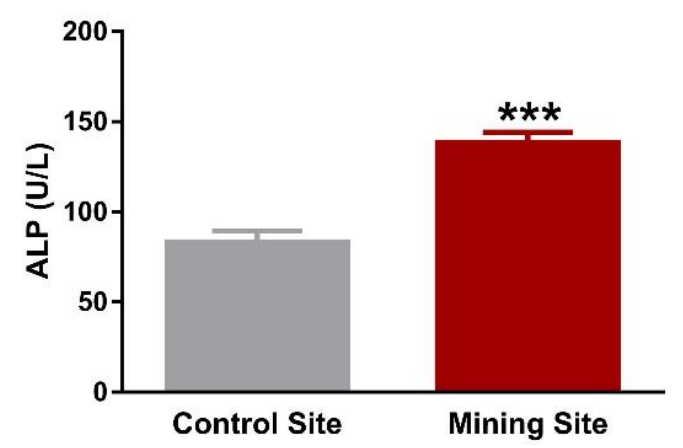

B

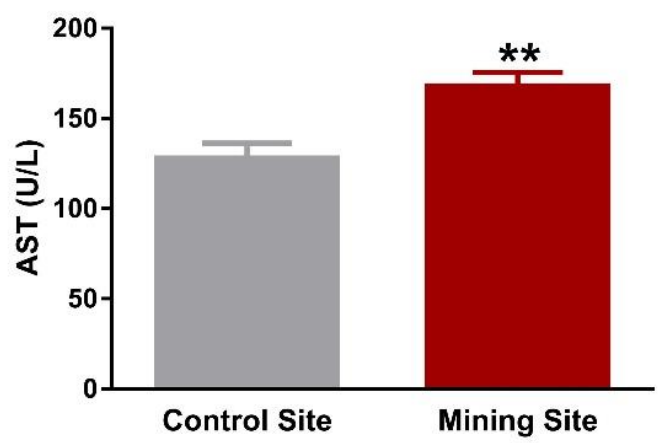

D

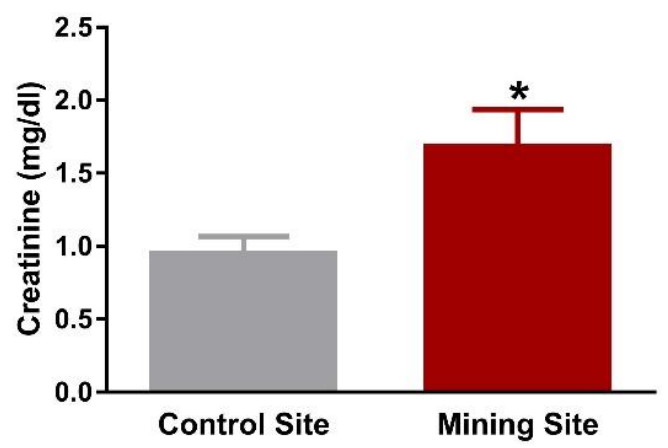

E

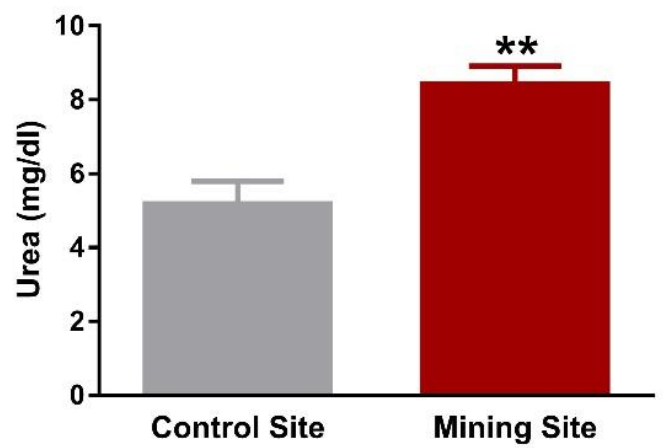

Figure 6. Liver and kidney function markers of S. senegalensis. ALT (A), AST (B), ALP (C), creatinine (D), and urea (E) were significantly elevated in serum of $S$. senegalensis from the mining site. Data are means $\pm \operatorname{SEM}(n=10) .{ }^{*} p<0.05,{ }^{* *} p<0.01$, and ${ }^{* *} p<0.001$ versus the Control site.

\subsection{Histopathological Changes Induced by Mining Activities in the Liver, Kidney, and Lung of S. senegalensis}

The impact of mining on S. senegalensis was further evaluated by the histological findings (Figure 7). Examination of the H\&E-stained liver section revealed normal structure of the hepatocytes and sinusoids in S. senegalensis from the reference site (Figure 7A,B). In contrast, the liver of S. senegalensis from the mining site showed histological alterations, including hepatocyte vacuolations and dilated central vein (Figure 7C,D). 

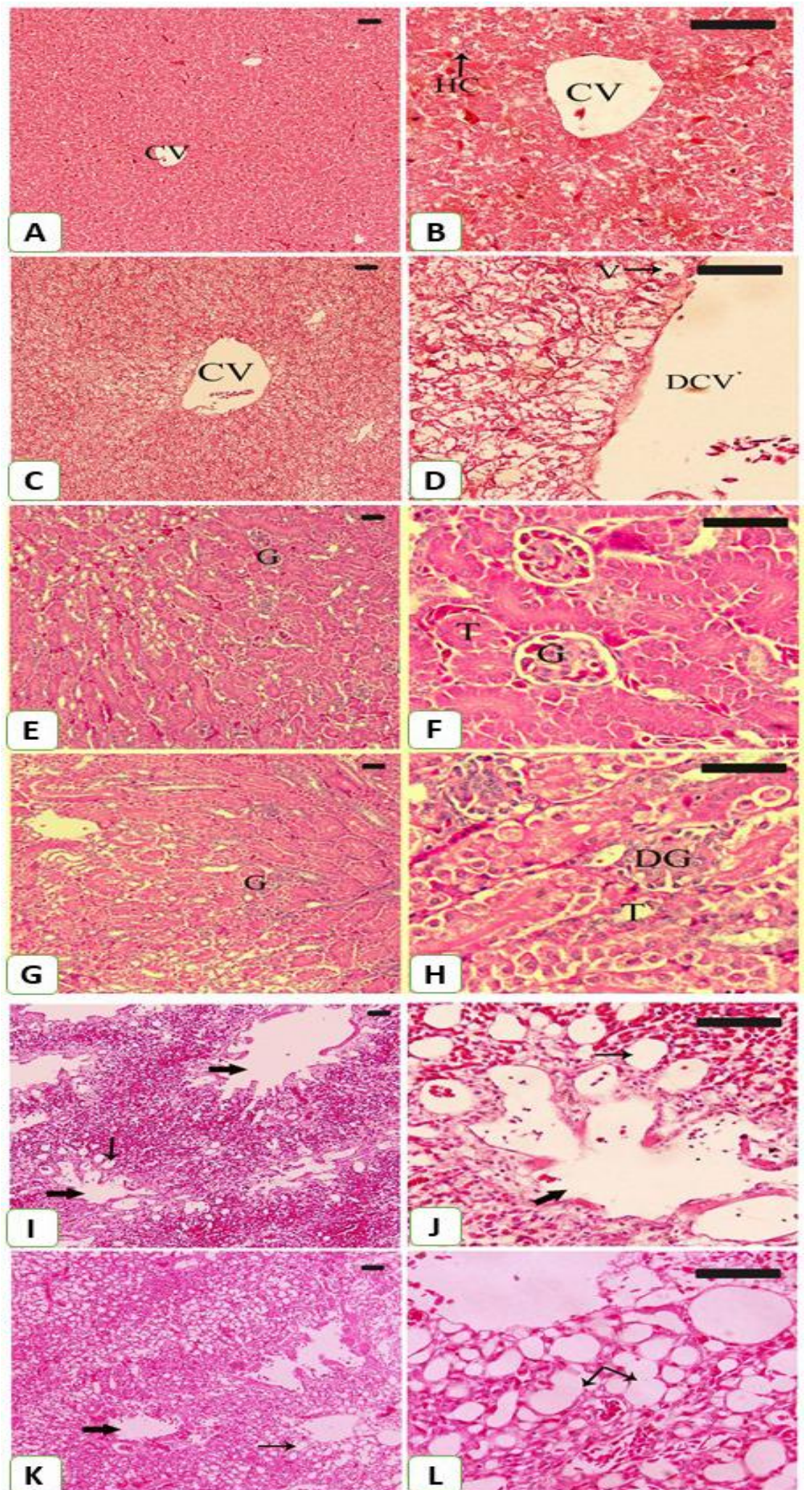

Figure 7. Photomicrographs of H\&E-stained sections in the liver (A-D), kidney (E-H) and lung (I-K) of $S$. senegalensis. Pigeons from the reference site showed normal hepatocytes (HC), central vein (CV) $(\mathbf{A}, \mathbf{B})$, glomeruli $(\mathbf{G})$, renal tubules $(\mathrm{T})(\mathbf{E}, \mathbf{F})$, alveoli and bronchioles (arrows) $(\mathbf{I}, \mathbf{J})$. Pigeons from the mining site showed dilated central vein (DCV), vacuolations (V) (C,D), degenerated glomeruli (DG), dilated renal tubules $(\mathrm{T})(\mathbf{G}, \mathbf{H})$, dilated alveoli and congested blood vessels (arrows) $(\mathbf{K}, \mathbf{L})$. (Scale bar = $100 \mu \mathrm{m})$. 
The kidney sections of $S$. senegalensis at the control site revealed normal capsule, cortex, medulla, glomeruli, and renal tubules (Figure $7 \mathrm{E}, \mathrm{F}$ ), whereas glomerular degeneration was observed in S. senegalensis from the mining site (Figure $7 \mathrm{G}, \mathrm{H}$ ).

The lung of $S$. senegalensis from the control site showed normal structure of the bronchioles and alveoli (Figure 7I,J). In contrast, the lung of S. senegalensis from the mining site showed dilated alveoli and congested blood vessels (Figure 7K,L).

\subsection{Mining Triggers Redox Imbalance in the Liver and Kidney of S. senegalensis}

To evaluate the impact of mining on the redox status in S. senegalensis, we determined LPO, NO, and antioxidants. S. senegalensis from the mining site exhibited a significant increase in liver and kidney LPO levels when compared with the reference sites birds $(p<0.001$; Figure $8 \mathrm{~A})$. NO showed a significant increase in the liver $(p<0.01)$ and kidney $(p<0.001)$ of $S$. senegalensis from the mining site (Figure $8 \mathrm{~B})$.

A

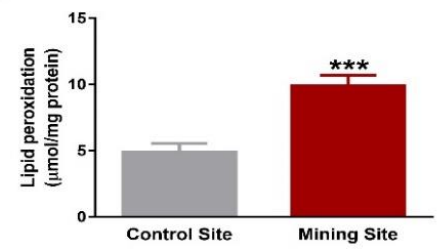

B

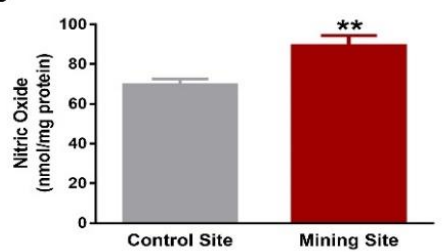

C

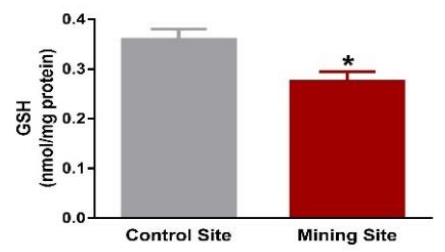

D

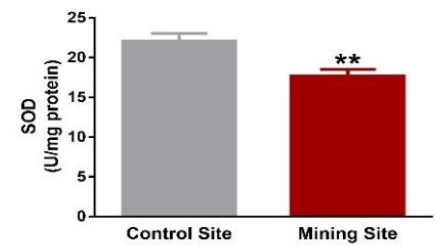

E

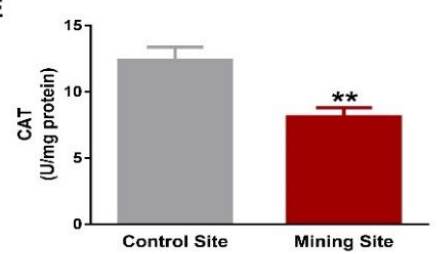

Kidney
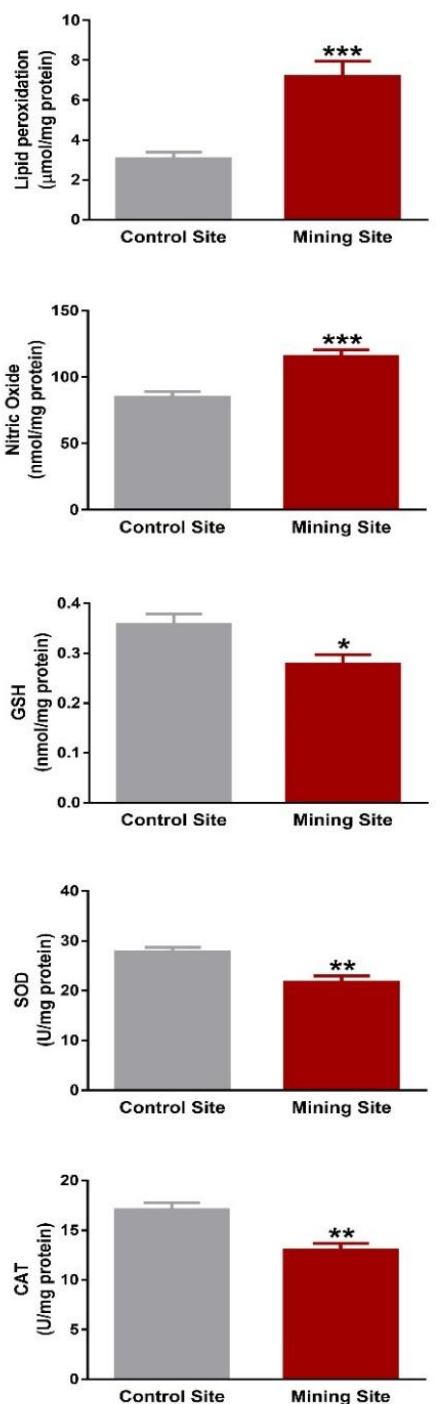

Figure 8. Oxidative stress markers and antioxidants in the liver and kidney of S. senegalensis. Hepatic and renal lipid peroxidation (A) and nitric oxide (B) were increased, and GSH (C), SOD (D), and CAT (E) were decreased in S. senegalensis from the mining site. Data are means $\pm \operatorname{SEM}(n=10) .{ }^{*} p<0.05$, ** $p<0.01$, and ${ }^{* * *} p<0.001$ versus the Control site. 
Hepatic and renal GSH contents were decreased $(p<0.05)$ in $S$. senegalensis from the mining site, as represented in Figure 8C. Similarly, SOD (Figure 8D) and CAT (Figure 8E) were decreased significantly $(p<0.01)$ in the liver and kidney of $S$. senegalensis from the mining site when compared with the control site.

\section{Discussion}

Environmental contamination is one of the undesirable effects of mining, and different HMs, including $\mathrm{Pb}, \mathrm{Cd}, \mathrm{Hg}, \mathrm{Zn}$, and $\mathrm{Cu}$, have been detected in the waste of mining [17]. Given their resistance to degradation, HMs can accumulate in the environment and cause negative impacts on the ecosystem and serious health problems $[18,19,23]$. Al-Quway'iyah, a big city in Riyadh (Saudi Arabia), is one of the sites of gold mining activities. We recently reported increased concentrations of HMs in the soil, plants, and different tissues of the Balochistan gerbil as a result of mining activities in Al-Quway'iyah [24]. The value of pigeons as biomonitors of environmental contamination has been recently demonstrated; therefore, we evaluated HM concentrations in different tissues of $S$. senegalensis at a gold mining site in Al-Quway'iyah, pointing to the resulted tissue damage and oxidative stress.

Analysis of metal(loid)s revealed an increase in $\mathrm{Pb}, \mathrm{Cd}, \mathrm{Hg}, \mathrm{V}, \mathrm{Cu}, \mathrm{Zn}, \mathrm{Mn}, \mathrm{Fe}$, and As concentrations in the liver, kidney, and lung of $S$. senegalensis at the site of gold mining activities. Accumulation of these metal(loid)s was associated with altered liver and kidney function, histological manifestations, and oxidative stress. S. senegalensis collected from the mining site showed increased serum ALT, AST, ALP, urea, and creatinine, demonstrating liver and kidney dysfunction. Aminotransferases and ALP are found inside the hepatocytes and their release into the circulation indicates hepatocyte damage. Creatinine and urea are commonly measured as indices of glomerular function $[27,28]$. Histological examination added support to the biochemical findings where hepatocyte vacuolations, dilated central vein, and glomerular degeneration were observed in the liver and kidney of $S$. senegalensis collected from the mining site. The tissue injury in S. senegalensis is directly connected to the increase in HMs and As concentrations, which are well-documented to pose a threat to different body organs [38].

$\mathrm{Pb}$ is a toxic $\mathrm{HM}$ with hazardous effects, ranging from mild physiological and biochemical disorders to severe pathological conditions. The exposure to $\mathrm{Pb}$ from agricultural and industrial activities is increasing [39]. The liver and kidney represent the main site for $\mathrm{Pb}$ deposition within the body [40] and this could explain the observed hepatic and renal tissue injury in S. senegalensis collected from the gold mining site. The toxicity of $\mathrm{Pb}$ is attributed to its ionic properties, where it can replace mono- and divalent cations in enzymes [41], and its ability to provoke excessive production of ROS and oxidative stress [42]. Increased ROS can trigger tissue injury through oxidizing lipids and proteins, inactivating antioxidant enzymes, and triggering DNA damage [31]. Accordingly, LPO and NO were increased and the antioxidants GSH, SOD, and CAT were decreased in both the liver and kidney of S. senegalensis collected from the site of mining activities. Besides liver and kidney injury, $\mathrm{Pb}$ was accumulated in the lungs of $S$. senegalensis, which showed histological alterations, an observation that was supported by our previous study showing the association between increased $\mathrm{Pb}$ concentration and tissue injury in the lungs of Gerbillus nanus collected from the same site [24]. Due to its highly toxic properties, $\mathrm{Pb}$ poisoning has been reported to cause the death of millions of birds each year [43].

$\mathrm{Cd}$, even in trace quantities, causes physiological and health problems in birds, such as reduced growth performance and reproduction [10]. In birds, Cd caused severe necrosis in seminiferous tubules and damage all stages of germ cells, as reviewed by Marettová et al. [44]. It is a very toxic and undegradable HM that accumulates in plants due to its high transfer rate from the soil, and reaches birds and humans through the food chain [45-47]. Accordingly, our recent work showed an increase in Cd concentration in both soil and plants at the mining site in Al-Quway'iyah [24]. Herein, $\mathrm{Cd}$ accumulated in the lung, liver, and kidney of S. senegalensis, which showed tissue injury and dysfunction accompanied with oxidative stress. In this context, $\mathrm{Cd}$ has been demonstrated to trigger hepato- and nephrotoxicity, mainly via promoting oxidative stress $[48,49]$. Hydrogen peroxide $\left(\mathrm{H}_{2} \mathrm{O}_{2}\right)$, which produces the highly toxic hydroxyl free radical through Fenton reaction, is produced by $\mathrm{Cd}$ 
within the body [50]. Upon entering the body, $\mathrm{Cd}$ is transported to the liver by albumin and forms complexes with metallothionine, thereby inducing liver injury. These complexes are transferred into the circulation and then accumulate and cause kidney injury [51,52]. Although cells are equipped with antioxidant enzymes which can counteract $\mathrm{Cd}$-mediated $\mathrm{H}_{2} \mathrm{O}_{2}$ production, the activity of SOD and CAT was declined in $S$. senegalensis at the mining site as a result of $\mathrm{Cd}$ binding with the thiol groups of these enzymes [53]. The hepato- and nephrotoxic effects of $\mathrm{Cd}$ in birds have been previously reported. For instance, $\mathrm{Cd}$ induced hepatotoxicity [54] and nephrotoxicity [55] by triggering lipid peroxidation and histological alterations in Gallus domesticus. Furthermore, Cd accumulated in the lungs of $S$. senegalensis collected from the mining site, which showed dilated alveoli and congested blood vessels, indicating pulmonary toxicity. Lungs are one of the main routes of $\mathrm{Cd}$ entrance into the body [46], and diminished pulmonary function [56] and bronchial irritation and inflammation [57] are reported effects of $\mathrm{Cd}$.

Mining is one of the main sources of $\mathrm{Hg}$, which accumulates in soil, plants, and tissues of the rodents [24]. This study showed increased levels of $\mathrm{Hg}$ in the kidneys, liver, and lungs of S. senegalensis collected from the mining site. $\mathrm{Hg}$ accumulation played a role in the nephro-, hepato-, and pulmonary toxicity observed in S. senegalensis. $\mathrm{Hg}$ has been reported to decrease fertility, egg weight, and embryonic growth, and induce kidney lesions in wild birds [5,8]. Both $\mathrm{Hg}$ and methylmercury trigger LPO and apoptosis, and therefore, cause nephro- and hepatotoxicity [58-60]. This study conferred new information that the hazardous effect of mining activities on birds is associated with increased concentrations of $\mathrm{Hg}$.

$\mathrm{V}$ and As are environmental pollutants produced through industrial activities, including mining, and can accumulate in plants and soil and affect wild animals [24]. Here, S. senegalensis collected from Al-Quway'iyah mining site showed increased concentrations of $\mathrm{V}$ and As, which are known to exert toxic effects. $V$ and its pentoxide caused occupational toxicity, chronic productive cough, and bronchial inflammation when inhaled [61,62], and triggered liver injury in rats [63]. As was found to be teratogenic in brooding birds and damage chromosomes in bone marrow cells of birds $[64,65]$. As genotoxicity has been postulated to be linked to excess ROS production, DNA damage, activation of apoptosis signaling, and replacing metal ions in enzymes and proteins [66]. The toxicity of As is associated with the formation of inorganic highly toxic and carcinogenic intermediates [67]. In birds, As compounds increased the incidence of renal tumors [64,65]. Moreover, exposure to As has been associated with liver, kidney, and lung injury in experimental animals [68-70]. Therefore, exposure of S. senegalensis to $\mathrm{V}$ and As at the mining site resulted in tissue injury and oxidative stress.

$\mathrm{Fe}, \mathrm{Zn}$, and $\mathrm{Cu}$ were also increased in the liver, kidney, and lung of $\mathrm{S}$. senegalensis collected from the mining site and could be associated with the observed tissue injury, dysfunction, and oxidative stress. $\mathrm{Cu}$ is potentially toxic as it exists in oxidized $[\mathrm{Cu}(\mathrm{II})]$ state in the environment and $\mathrm{ROS}$ are generated during its transition into the reduced form [71]. Fe and Zn are essential for many cell functions; however, they are toxic at concentrations beyond the physiological limits. Increased Fe is associated with hepatotoxicity [72] and nephrotoxicity [73], and high Zn concentrations can replace essential elements or interact with the sulfhydryl groups of multiple proteins [74]. Zn concentrations in the liver, kidney, and lung of S. senegalensis were found to be higher than other HMs. Although it is required for the function of a large number of enzymes and transcription factors within the body, high $\mathrm{Zn}$ concentration can be harmful [75]. Therefore, accumulation of $\mathrm{Fe}, \mathrm{Zn}$, and $\mathrm{Cu}$ can induce oxidative stress and tissue injury.

The accumulation of HMs in different tissues of pigeons collected from contaminated regions was reported in previous studies; however, the impact of gold mining on S. senegalensis has not been reported, at least not in Saudi Arabia. The feral pigeons (Columba livia) collected from a ferronickel smelter courtyard in Drenas (Kosovo) exhibited significantly increased concentrations of $\mathrm{Pb}, \mathrm{Cd}$, $\mathrm{Zn}, \mathrm{Cu}$, and $\mathrm{Ni}$ in the liver, kidney, and other tissues when compared with pigeons collected from a control site [76]. Feral pigeons from the same area (Drenas, Kosovo) showed liver dysfunction and accumulation of HMs in different tissues [77]. Hence, the feral pigeon has been suggested 
as a biomonitoring organism for the evaluation of environmental pollution caused by ferronickel industry [77]. In addition, the accumulation of $\mathrm{Pb}$ and $\mathrm{Cd}$ in tissues of feral pigeons collected near central London has been demonstrated [78]. The findings of this study suggest the value of the feral pigeon to monitor urban $\mathrm{Pb}$ contamination and as a model for chronic $\mathrm{Pb}$ toxicity [78].

\section{Conclusions}

The current findings introduce information on the value of $S$. senegalensis as a biomonitor of environmental contamination caused by mining activities. The results showed an increase in the concentrations of $\mathrm{Pb}, \mathrm{Cd}, \mathrm{Hg}, \mathrm{V}, \mathrm{As}, \mathrm{Zn}, \mathrm{Fe}$, and $\mathrm{Cu}$, histopathological alterations, increased lipid peroxidation, and decreased antioxidant defenses in different tissues of $S$. senegalensis collected from the mining site. These data closely reflect the differences in HM concentrations between the mining and control sites and suggest that $S$. senegalensis provide valuable data for evaluating the impact of environmental pollutants. Moreover, this study might present the scientific basis for employing $S$. senegalensis in epidemiological avian studies of human health.

Author Contributions: Conceptualization, A.M.M., J.A., and A.A.A.; methodology, A.M.A., A.M.M., J.A., A.A.A., and H.A.E.-S.; validation, J.A., A.A.A., and A.M.M.; formal analysis, A.M.M.; investigation, A.M.A., A.M.M., J.A., A.A.A., S.N.M., and H.A.E.-S.; resources, A.M.M. and J.A.; data curation, A.M.A. and A.M.M.; writing-original draft preparation, A.M.M.; writing-review and editing, A.M.M.; visualization, J.A., A.A.A., A.M.M., and H.A.E.-S.; supervision, A.M.M., J.A., H.A.E.-S., and A.A.A.; project administration, J.A. and A.A.A.; funding acquisition, J.A.

Funding: This research was funded by the Dean of Scientific Research, King Saud University, grant number RGP-VPP-240.

Acknowledgments: The authors extend their appreciation to the Dean of Scientific Research, King Saud University, for funding the work through the research group project number RGP-VPP-240.

Conflicts of Interest: The authors declare no conflicts of interest.

\section{References}

1. Carignan, V.; Villard, M.A. Selecting indicator species to monitor ecological integrity: A review. Environ. Monit. Assess. 2002, 78, 45-61. [CrossRef] [PubMed]

2. Zaidi, B.R.; Imam, S.H. Biodegradability. In Encyclopedia of Ecology; Jørgensen, S.E., Fath, B.D., Eds.; Academic Press: Oxford, UK, 2008; pp. 357-366.

3. Chambers, S.A.; Birds, A.; Parks, V. Birds As Environmental Indicators: Review of Literature; Parks Victoria: Melbourne, Australia, 2008.

4. Gregory, R.D.; van Strien, A.; Vorisek, P.; Gmelig Meyling, A.W.; Noble, D.G.; Foppen, R.P.B.; Gibbons, D.W. Developing indicators for european birds. Philos. Trans. R. Soc. B Biol. Sci. 2005, 360, 269-288. [CrossRef] [PubMed]

5. Francis, E.A. Paramount roles of wild birds as bioindicators of contamination. Int. J. Avian Wildl. Biol. 2017, 2, 00041. [CrossRef]

6. Lindberg, P.; Sellström, U.; Häggberg, L.; de Wit, C.A. Higher brominated diphenyl ethers and hexabromocyclododecane found in eggs of peregrine falcons (falco peregrinus) breeding in sweden. Environ. Sci. Technol. 2004, 38, 93-96. [CrossRef] [PubMed]

7. Bonisoli-Alquati, A. Avian genetic ecotoxicology: DNA of the canary in a coalmine. Curr. Zool. 2014, 60, 285-298. [CrossRef]

8. Salamat, N.; Etemadi-Deylami, E.; Movahedinia, A.; Mohammadi, Y. Heavy metals in selected tissues and histopathological changes in liver and kidney of common moorhen (gallinula chloropus) from anzali wetland, the south caspian sea, iran. Ecotoxicol. Environ. Saf. 2014, 110, 298-307. [CrossRef]

9. Eeva, T.; Belskii, E.; Gilyazov, A.S.; Kozlov, M.V. Pollution impacts on bird population density and species diversity at four non-ferrous smelter sites. Biol. Conserv. 2012, 150, 33-41. [CrossRef]

10. Liu, J.; Liang, J.; Yuan, X.; Zeng, G.; Yuan, Y.; Wu, H.; Huang, X.; Liu, J.; Hua, S.; Li, F.; et al. An integrated model for assessing heavy metal exposure risk to migratory birds in wetland ecosystem: A case study in dongting lake wetland, china. Chemosphere 2015, 135, 14-19. [CrossRef] 
11. Cui, J.; Halbrook, R.S.; Zang, S.; You, J. Use of homing pigeons as biomonitors of atmospheric metal concentrations in beijing and guangzhou, china. Ecotoxicology 2016, 25, 439-446. [CrossRef]

12. Krook, J.; Svensson, N.; Eklund, M. Landfill mining: A critical review of two decades of research. Waste Manag. 2012, 32, 513-520. [CrossRef]

13. Loayza, N.; Rigolini, J. The local impact of mining on poverty and inequality: Evidence from the commodity boom in peru. World Dev. 2016, 84, 219-234. [CrossRef]

14. Emmanuel, A.Y.; Jerry, C.S.; Dzigbodi, D.A. Review of environmental and health impacts of mining in ghana. J. Health Pollut. 2018, 8, 43-52. [CrossRef] [PubMed]

15. Dudka, S.; Adriano, D.C. Environmental impacts of metal ore mining and processing: A review. J. Environ. Qual. 1997, 26, 590-602. [CrossRef]

16. Warhate, S.R.; Yenkie, M.K.; Chaudhari, M.D.; Pokale, W.K. Impacts of mining activities on water and soil. J. Environ. Sci. Eng. 2006, 48, 81-90. [PubMed]

17. Fashola, M.O.; Ngole-Jeme, V.M.; Babalola, O.O. Heavy metal pollution from gold mines: Environmental effects and bacterial strategies for resistance. Int. J. Environ. Res. Public Health 2016, 13, 1047. [CrossRef]

18. Jarup, L. Hazards of heavy metal contamination. Br. Med. Bull. 2003, 68, 167-182. [CrossRef]

19. Rzymski, P.; Niedzielski, P.; Klimaszyk, P.; Poniedzialek, B. Bioaccumulation of selected metals in bivalves (unionidae) and phragmites australis inhabiting a municipal water reservoir. Environ. Monit. Assess. 2014, 186, 3199-3212. [CrossRef]

20. Rzymski, P.; Tomczyk, K.; Rzymski, P.; Poniedzialek, B.; Opala, T.; Wilczak, M. Impact of heavy metals on the female reproductive system. Ann. Agric. Environ. Med. 2015, 22, 259-264. [CrossRef]

21. De Kok, T.M.; Hogervorst, J.G.; Briede, J.J.; van Herwijnen, M.H.; Maas, L.M.; Moonen, E.J.; Driece, H.A.; Kleinjans, J.C. Genotoxicity and physicochemical characteristics of traffic-related ambient particulate matter. Environ. Mol. Mutagen. 2005, 46, 71-80. [CrossRef]

22. Markiewicz-Górka, I.; Januszewska, L.; Michalak, A.; Prokopowicz, A.; Januszewska, E.; Pawlas, N.; Pawlas, K. Effects of chronic exposure to lead, cadmium, and manganese mixtures on oxidative stress in rat liver and heart. Arch. Ind. Hyg. Tokxicol. 2015, 66, 51-62.

23. Singh, R.; Gautam, N.; Mishra, A.; Gupta, R. Heavy metals and living systems: An overview. Indian J. Pharmacol. 2011, 43, 246-253. [CrossRef] [PubMed]

24. Almalki, A.M.; Ajarem, J.; Altoom, N.; Al-Otaibi, F.S.; Maodaa, S.N.; Allam, A.A.; Mahmoud, A.M. Effects of mining activities on gerbillus nanus in saudi arabia: A biochemical and histological study. Animals 2019, 9, 664. [CrossRef]

25. Al-Otaibi, F.S.; Ajarem, J.S.; Abdel-Maksoud, M.A.; Maodaa, S.; Allam, A.A.; Al-Basher, G.I.; Mahmoud, A.M. Stone quarrying induces organ dysfunction and oxidative stress in meriones libycus. Toxicol. Ind. Health 2018, 34, 679-692. [CrossRef] [PubMed]

26. Bancroft, J.A.; Stevens, A. Theory and Practice of Histological Techniques; Churchill Livingstone: New York, NY, USA, 1996.

27. Gowda, S.; Desai, P.B.; Kulkarni, S.S.; Hull, V.V.; Math, A.A.; Vernekar, S.N. Markers of renal function tests. N. Am. J. Med. Sci. 2010, 2, 170. [PubMed]

28. Salazar, J.H. Overview of urea and creatinine. Lab. Med. 2014, 45, e19-e20. [CrossRef]

29. Halliwell, B.; Gutteridge, J.M.C. Free Radicals in Biology and Medicine, 5th ed.; Oxford University Press: Oxford, MS, USA, 2015.

30. Salmon, P.; Stroh, E.; Herrera-Duenas, A.; von Post, M.; Isaksson, C. Oxidative stress in birds along a nox and urbanisation gradient: An interspecific approach. Sci. Total Environ. 2018, 622, 635-643. [CrossRef]

31. Martindale, J.L.; Holbrook, N.J. Cellular response to oxidative stress: Signaling for suicide and survival. J. Cell. Physiol. 2002, 192, 1-15. [CrossRef]

32. Preuss, H.G.; Jarrell, S.T.; Scheckenbach, R.; Lieberman, S.; Anderson, R.A. Comparative effects of chromium, vanadium and gymnema sylvestre on sugar-induced blood pressure elevations in shr. J. Am. Coll. Nutr. 1998, 17, 116-123. [CrossRef]

33. Grisham, M.B.; Johnson, G.G.; Lancaster, J.R., Jr. Quantitation of nitrate and nitrite in extracellular fluids. Methods Enzymol. 1996, 268, 237-246.

34. Beutler, E.; Duron, O.; Kelly, B.M. Improved method for the determination of blood glutathione. J. Lab. Clin. Med. 1963, 61, 882-888. 
35. Marklund, S.; Marklund, G. Involvement of the superoxide anion radical in the autoxidation of pyrogallol and a convenient assay for superoxide dismutase. FEBS Eur. J. Biochem. 1974, 47, 469-474. [CrossRef] [PubMed]

36. Cohen, G.; Dembiec, D.; Marcus, J. Measurement of catalase activity in tissue extracts. Anal. Biochem. 1970, 34, 30-38. [CrossRef]

37. Bradford, M.M. A rapid and sensitive method for the quantitation of microgram quantities of protein utilizing the principle of protein-dye binding. Anal. Biochem. 1976, 72, 248-254. [CrossRef]

38. Jaishankar, M.; Tseten, T.; Anbalagan, N.; Mathew, B.B.; Beeregowda, K.N. Toxicity, mechanism and health effects of some heavy metals. Interdiscip. Toxicol. 2014, 7, 60-72. [CrossRef] [PubMed]

39. World Health Organization. Lead Poisoning and Health. 2018. Available online: https://www.who.int/newsroom/fact-sheets/detail/lead-poisoning-and-health (accessed on 1 May 2019).

40. Mudipalli, A. Lead hepatotoxicity \& potential health effects. Indian J. Med. Res. 2007, 126, 518-527.

41. Flora, S.J.S.; Flora, G.; Saxena, G. Environmental occurrence, health effects and management of lead poisoning. In Lead Chemistry, Analytical Aspects, Environmental Impacts and Health Effects; Cascas, S.B., Sordo, J., Eds.; Elsevier Publication: Amsterdam, The Netherlands, 2006; pp. 158-228.

42. Adegbesan, B.O.; Adenuga, G.A. Effect of lead exposure on liver lipid peroxidative and antioxidant defense systems of protein-undernourished rats. Biol. Trace Elem. Res. 2007, 116, 219-225. [CrossRef]

43. De Francisco, N.; Ruiz Troya, J.D.; Aguera, E.I. Lead and lead toxicity in domestic and free living birds. Avian Pathol. 2003, 32, 3-13. [CrossRef]

44. Marettova, E.; Maretta, M.; Legath, J. Toxic effects of cadmium on testis of birds and mammals: A review. Anim. Reprod. Sci. 2015, 155, 1-10. [CrossRef]

45. Jarup, L.; Akesson, A. Current status of cadmium as an environmental health problem. Toxicol. Appl. Pharmacol. 2009, 238, 201-208. [CrossRef]

46. Thevenod, F; Lee, W.K. Toxicology of cadmium and its damage to mammalian organs. In Cadmium: From Toxicity to Essentiality; Springer: Dordrecht, The Netherlands, 2013; Volume 11, pp. 415-490.

47. Satarug, S.; Garrett, S.H.; Sens, M.A.; Sens, D.A. Cadmium, environmental exposure, and health outcomes. Cienc. Saude Coletiva 2011, 16, 2587-2602. [CrossRef]

48. Jeyaprakash, K.; Chinnaswamy, P. Effect of spirulina and liv-52 on cadmium induced toxicity in albino rats. Indian J. Exp. Biol. 2005, 43, 773-781. [PubMed]

49. Vicente-Sanchez, C.; Egido, J.; Sanchez-Gonzalez, P.D.; Perez-Barriocanal, F.; Lopez-Novoa, J.M.; Morales, A.I. Effect of the flavonoid quercetin on cadmium-induced hepatotoxicity. Food Chem. Toxicol. 2008, 46, 2279-2287. [CrossRef] [PubMed]

50. Casalino, E.; Sblano, C.; Landriscina, C. Enzyme activity alteration by cadmium administration to rats: The possibility of iron involvement in lipid peroxidation. Arch. Biochem. Biophys. 1997, 346, 171-179. [CrossRef] [PubMed]

51. Shimada, H.; Yasutake, A.; Hirashima, T.; Takamure, Y.; Kitano, T.; Waalkes, M.P.; Imamura, Y. Strain difference of cadmium accumulation by liver slices of inbred wistar-imamichi and fischer 344 rats. Toxicol. In Vitro 2008, 22, 338-343. [CrossRef]

52. Castagnetto, J.M.; Hennessy, S.W.; Roberts, V.A.; Getzoff, E.D.; Tainer, J.A.; Pique, M.E. Mdb: The metalloprotein database and browser at the scripps research institute. Nucl. Acids Res. 2002, 30, 379-382. [CrossRef]

53. Wang, Y.; Fang, J.; Leonard, S.S.; Rao, K.M. Cadmium inhibits the electron transfer chain and induces reactive oxygen species. Free Radic. Biol. Med. 2004, 36, 1434-1443. [CrossRef]

54. Li, J.L.; Jiang, C.Y.; Li, S.; Xu, S.W. Cadmium induced hepatotoxicity in chickens (gallus domesticus) and ameliorative effect by selenium. Ecotoxicol. Environ. Saf. 2013, 96, 103-109. [CrossRef]

55. Hesaraki, S.; Gharagozlou, M.J.; Salar Amoli, J.; Javaheri Vaighan, A.; Bokaei, S. Histopathological and ultrastractural changes ofkidneys in response to cadmium chloride toxicityin broiler chickens. J. Vet. Res. 2010, 65, 281-288.

56. Oberdorster, G. Airborne cadmium and carcinogenesis of the respiratory tract. Scand. J. Work Environ. Health 1986, 12, 523-537. [CrossRef] 
57. Bolognin, M.; Kirschvink, N.; Leemans, J.; De Buscher, V.; Snaps, F.; Gustin, P.; Peeters, D.; Clercx, C. Characterisation of the acute and reversible airway inflammation induced by cadmium chloride inhalation in healthy dogs and evaluation of the effects of salbutamol and prednisolone. Vet. J. 2009, 179, 443-450. [CrossRef]

58. Patrick, L. Mercury toxicity and antioxidants: Part 1: Role of glutathione and alpha-lipoic acid in the treatment of mercury toxicity. Altern. Med. Rev. 2002, 7, 456-471. [PubMed]

59. Boroushaki, M.T.; Mollazadeh, H.; Rajabian, A.; Dolati, K.; Hoseini, A.; Paseban, M.; Farzadnia, M. Protective effect of pomegranate seed oil against mercuric chloride-induced nephrotoxicity in rat. Ren. Fail. 2014, 36, 1581-1586. [CrossRef] [PubMed]

60. Brandao, F.; Cappello, T.; Raimundo, J.; Santos, M.A.; Maisano, M.; Mauceri, A.; Pacheco, M.; Pereira, P. Unravelling the mechanisms of mercury hepatotoxicity in wild fish (liza aurata) through a triad approach: Bioaccumulation, metabolomic profiles and oxidative stress. Metallomics 2015, 7, 1352-1363. [CrossRef] [PubMed]

61. Assem, F.L.; Levy, L.S. Inhalation toxicity of vanadium. In Vanadium: Biochemical and Molecular Biological Approaches; Michibata, H., Ed.; Springer: Dordrecht, The Netherlands, 2012; pp. 209-224.

62. Altamirano-Lozano, M.A.; Alvarez-Barrera, L.; Mateos-Nava, R.A.; Fortoul, T.I.; Rodriguez-Mercado, J.J. Potential for genotoxic and reprotoxic effects of vanadium compounds due to occupational and environmental exposures: An article based on a presentation at the 8th international symposium on vanadium chemistry, biological chemistry, and toxicology, washington dc, august 15-18, 2012. J. Immunotoxicol. 2014, 11, $19-27$. [PubMed]

63. Castellini, C.; Mourvaki, E.; Sartini, B.; Cardinali, R.; Moretti, E.; Collodel, G.; Fortaner, S.; Sabbioni, E.; Renieri, T. In vitro toxic effects of metal compounds on kinetic traits and ultrastructure of rabbit spermatozoa. Reproduct. Toxicol. 2009, 27, 46-54. [CrossRef] [PubMed]

64. Egwumah, F.; Egwumah, P.; Tyowua, B. Evaluation of black-headed oriole oriolus brachyrhynchus (swainson, 1837) as bioindicator of arsenic contamination using atomic absorption spectrometry (aas). J. Agric. Ecol. Res. Int. 2017, 12, 1-9. [CrossRef]

65. World Health, O. Arsenic in Drinking Water; IWA: London, UK, 2001.

66. Hughes, M.F.; Beck, B.D.; Chen, Y.; Lewis, A.S.; Thomas, D.J. Arsenic exposure and toxicology: A historical perspective. Toxicol. Sci. 2011, 123, 305-332. [CrossRef]

67. Singh, N.; Kumar, D.; Sahu, A.P. Arsenic in the environment: Effects on human health and possible prevention. J. Environ. Biol. 2007, 28, 359-365.

68. Thangapandiyan, S.; Ramesh, M.; Miltonprabu, S.; Hema, T.; Jothi, G.B.; Nandhini, V. Sulforaphane potentially attenuates arsenic-induced nephrotoxicity via the pi3k/akt/nrf2 pathway in albino wistar rats. Environ. Sci. Pollut. Res. 2019, 26, 12247-12263. [CrossRef]

69. Ling, S.; Shan, Q.; Liu, P.; Feng, T.; Zhang, X.; Xiang, P.; Chen, K.; Xie, H.; Song, P.; Zhou, L.; et al. Metformin ameliorates arsenic trioxide hepatotoxicity via inhibiting mitochondrial complex i. Cell Death Dis. 2017, 8, e3159. [CrossRef]

70. Mariappan, N.; Zafar, I.; Husain, M.; Vaid, M.; Surolia, R.; Kashyap, M.P.; Srivastava, R.; Ahmad, S.; Agarwal, A.; Athar, M.; et al. Pulmonary manifestations of inhaled arsenic trioxide following an acute accidental exposure. In B31. Acute Lung Injury and Ards: Translational and Mechanistic Studies; American Thoracic Society: Dallas, TX, USA, 2018; p. A2974.

71. Stern, B.R. Essentiality and toxicity in copper health risk assessment: Overview, update and regulatory considerations. J. Toxicol. Environ. Health Part A 2010, 73, 114-127. [CrossRef] [PubMed]

72. Ramm, G.A.; Ruddell, R.G. Hepatotoxicity of iron overload: Mechanisms of iron-induced hepatic fibrogenesis. Semin. Liver Dis. 2005, 25, 433-449. [CrossRef] [PubMed]

73. Zager, R.A.; Johnson, A.C.M.; Hanson, S.Y. Parenteral iron nephrotoxicity: Potential mechanisms and consequences1. Kidney Int. 2004, 66, 144-156. [CrossRef] [PubMed]

74. Kox, L.F.; Wosten, M.M.; Groisman, E.A. A small protein that mediates the activation of a two-component system by another two-component system. EMBO J. 2000, 19, 1861-1872. [CrossRef]

75. Plum, L.M.; Rink, L.; Haase, H. The essential toxin: Impact of zinc on human health. Int. J. Environ. Res. Public Health 2010, 7, 1342-1365. [CrossRef]

76. Milaimi, A.P.; Selimi, Q.; Letaj, K.; Trebicka, A.; Milaimi, A. Accumulation of heavy metals in feral pigeons living near a ferronickel smelter. Pol. J. Environ. Stud. 2016, 25, 2695-2699. [CrossRef] 
77. Elezaj, I.; Selimi, Q.; Letaj, K.; Plakiqi, A.; Mehmeti, S.I.; Milaimi, A.P. Metal bioaccumulation, enzymatic activity, total protein and hematology of feral pigeon (columba livia), living in the courtyard of ferronickel smelter in drenas. J. Chem. Health Risks 2011, 1, 1-6.

78. Hutton, M.; Goodman, G.T. Metal contamination of feral pigeons columba livia from the london area: Part 1-Tissue accumulation of lead, cadmium and zinc. Environ. Pollut. Ser. A Ecol. Biol. 1980, 22, 207-217. [CrossRef]

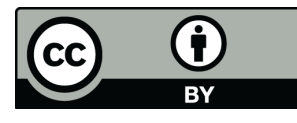

(C) 2019 by the authors. Licensee MDPI, Basel, Switzerland. This article is an open access article distributed under the terms and conditions of the Creative Commons Attribution (CC BY) license (http://creativecommons.org/licenses/by/4.0/). 